\title{
Analysis of Competitive Strategy Development Using Meta-SWOT Approach in PT. Velesia
}

\author{
Christin Susilowati ${ }^{1, *}$ Muhammad Rambang Sinuling ${ }^{2}$
}

\author{
${ }^{1,2}$ Brawijaya University \\ *Corresponding author. Email: christin@ub.ac.id
}

\begin{abstract}
The rapid development of the craft and fashion industry has made business competition in the industry more competitive. It makes businesspeople have to develop strategies to survive and win the competition. This study aims to analyze and determine the development of a competitive strategy that is appropriate for the company. Data were obtained from observation, in-depth interviews, questionnaires, documentation, and literature studies. This study used four informants, namely the head of the branch of PT. Velesia, head of general affairs/ HRD of PT. Velesia, marketing helper staff of PT. Velesia and director of a major competitor (CV. Bhumi Cipta Mandiri). The analytical technique used in this study is Meta-SWOT analysis which analyzes internal factors with a resource-based view analysis and external factors with PESTEL analysis. Based on the results of the Meta-SWOT analysis, the quadrant position of PT. Velesia is in quadrant I of the grand strategy matrix, which indicates the right competitive strategy for PT. Velesia is market penetration, market development and product development. The penetration strategy that can be done by PT. Velesia increases promotions, maintains prices, adds workers, and cooperates with other companies. The market development strategy that the company can do is to expand the market segment targeted by the company. Product development strategy that can be done by PT. Velesia is conducting market research on the types of bag products that are becoming a trend, creating new product lines, improving product quality, strengthening product values and collaborating with designers.
\end{abstract}

Keywords: Strategy Development, Competitive Strategy, Internal Environment, External Environment, IFE Matrix, EFE Matrix, Resource Based View, PESTEL, Meta-SWOT, Grand Strategy Matrix.

\section{INTRODUCTION}

The rapid development of the craft and fashion industry has made business competition in the industry becomes more competitive. The rapid technological advancement helps realize the advanced and growing craft industry with the many facilities and online platforms provided, quoted from President Jokowi's state speech at the MPR annual session, in 2020 alone, the value of Indonesia's digital trade transactions reached more than Rp. 253 trillion [1]. Technological advancement also affects the delivery of information that can drive fashion trends. On the other hand, the competition in Indonesia's craft and fashion industry sector is increasingly competitive. Based on the 2020 Focus Economy Outlook, the creative economy contributed Rp. 1.100 trillion of Indonesia's Gross Domestic Product (GDP) throughout 2020 [2, 11]. This condition requires business actors to find the right strategy to win the competition. Business actors must correctly identify opportunities, threats, strengths, and weaknesses (SWOT) owned by the external and internal environment that exists in their business. SWOT owned by a business is the basis for identifying what competitive strengths it has and for formulating the right strategy in order to survive and win the competition. Thus the company's goals can be achieved.

PT. Velesia is one of the companies engaged in the craft and fashion industry, which is the focus of this study. PT. Velesia is a manufacturer of bag craft products with unique product characteristics, namely in the form of handmade knitted bags. The development of the industry has led to increased competition as well as the emergence of new competitors by bringing offering capacity with increasingly diverse products. This leads PT. Veleseia to find its strength and weaknesses to 
identify its competitive strength, which will be the basis for formulating strategies.

The use of the right analytical tools greatly determines the accuracy of the identification of each component needed for strategic decision-making. The analytical tool used in this study is Meta-SWOT analysis, which is a form of SWOT analysis development. The Meta-SWOT method seeks to eliminate the shortcomings of SWOT to be more future-oriented, accurate, resource-efficient, objective, useful, and timely. Meta-SWOT analyzes the internal and external environment through the Resource-Based View (RBV) and PESTEL approach [3] to achieve competitive advantage. Using this approach, companies can find the value that do not owned by their competitors.

\section{THEORETICAL BASIS}

\subsection{Strategy}

Strategy is the determination of the company's long-term goals and objectives, the implementation of actions and the allocation of resources needed to achieve the goals that have been set [15].

\subsection{Strategic Management}

Strategic management is a set of decision and action that determine company performance in the long term [5].

Strategic Management is what managers do to develop an organization's strategy [15].

Strategic management is a series of decisions and actions that result in formulating and implementing plans to achieve company goals [12].

\subsection{Competitive Strategy}

Competitive strategy is a search for a competitive position beneficial in an industry, which is the whole place where competition occurs (Porter, 1985) [18].

\subsection{Meta-SWOT}

One of the methods used since 2012 is Meta SWOT strategic planning. Meta SWOT is an inwardlooking strategic planning method that helps us to win in competing with competitors in the future by identifying and evaluating our competition scene with others and identifying the resources and capabilities of our internal environment and changing our economic borders or common markets with competitors (Amiin et al. 1,2021) [4]. Meta-SWOT is intrinsically a strategic planning methodology that helps managers develop new and useful strategies by identifying and assessing their competitive scene and resources and capabilities within their environment (Habib et al. 1, 2018) [9]. Meta-SWOT is a form of development of SWOT analysis. Meta-SWOT eliminates weaknesses of SWOT by being more oriented to the future, accurate, resource-centered, objective, useful, and on time [3]. There are 4 stages in this analysis [7], namely:

\subsubsection{Input of Decision "Resources and Competition"}

At this stage, identifying organizational resources and capabilities with critical success factors is carried out along with identifying organizational competitiveness by choosing competitors with the same business scale compared to the company.

\subsubsection{Output Screen "Competitive Map"}

At this stage, the informant gives a score of 1-5 to assess the company's resources and capabilities.

\subsubsection{Input of Decision "(V)RIO and Business Environment"}

At this stage, an evaluation of resources and capability (rarity, imitability, and organization), calculation of IFE matrix, identification of external environment (PESTEL), and calculation of EFE matrix are carried out.

\subsubsection{Output Screen "Strategy"}

At this stage, the results of the evaluation of the external and internal environment are entered into the grand strategy matrix to determine the appropriate competitive strategy.

\subsection{Resource Based-View}

Resource Based-View (RBV) is a method to analyze and identify the strategic advantage of a company that is based on a review to a combination of assets, skills, capabilities, and intangible assets that are valuable to the organization (Pearce and

Robinson, 2018 p.170) [12]. 
RBV is an inside-out perspective of the organization that seeks to identify the characteristics of firms with superior performance (Rouse and Daellenbach, 2002, p. 966) [20].

\subsection{PESTEL Analysis}

PESTEL analysis is an external analysis carried out when companies conduct market research, and it provides a comprehensive picture regarding the aspects of the external environment that must be considered by the company [7].

\section{RESEARCH METHODOLOGY}

The data collection method used in this study is observation and in-depth interview using questionnaire, documentation, and literature study [10]. The data and information in this study is obtained from four informants, namely branch head of PT. Velesia, head of general affairs/HRD of PT. Velesia, marketing helper staff of PT. Velesia, and director of a major competitor. The selection is based on the consideration that the informant has the information and competence in accordance with the objectives set out in the study. The informants have sufficient data and information as a basis for analysis in this study.

\section{RESULTS AND DISCUSSION}

\subsection{Input of Decisions "Resources and Competition"}

There are 12 resources and internal capabilities of PT. Velesia has critical success factors, namely brand awareness, the marketing media network, market expansion, procurement management, quality control, key suppliers, information technology, employee loyalty, work culture, employee development and training, and competitive selling prices.

Table 1. Resource and Capabilities of PT. Velesia

\begin{tabular}{|l|l|}
\hline \multirow{4}{*}{ Marketing } & \multicolumn{1}{|c|}{ Resource and Capabilities } \\
\cline { 2 - 2 } & Brand Awareness \\
\cline { 2 - 2 } & Marketing Media Network \\
\cline { 2 - 2 } & Market Expansion \\
\hline \multirow{5}{*}{ Operational } & Procurement Management \\
\cline { 2 - 2 } & Quality Control \\
\cline { 2 - 2 } & Key Supplier \\
\cline { 2 - 2 } & Information Technology \\
\hline Human & Employee Loyalty \\
\cline { 2 - 2 } & Work Culture \\
\hline
\end{tabular}

\begin{tabular}{|l|l|}
\hline & Empoyee Training and Development \\
\hline Finance & Competitive Selling Prices \\
\hline
\end{tabular}

\subsection{Output Screen "Competitive Map"}

It shows that position of PT. Velesia is still on the first rank when the resources and capabilities are compared to its competitors.

Table 2. Competitive Map

\begin{tabular}{|c|c|c|}
\hline Resources and Capabilities & $\begin{array}{c}\text { PT. } \\
\text { Velesia }\end{array}$ & $\begin{array}{l}\text { CV. } \\
\mathrm{BCM}\end{array}$ \\
\hline Brand Awareness & 5 & 4 \\
\hline Marketing Media Network & 4 & 3 \\
\hline Market Expansion & 4 & 3 \\
\hline Procurement Management & 4 & 5 \\
\hline Quality Control & 5 & 5 \\
\hline Key Supplier & 5 & 4 \\
\hline Information Technology & 3 & 4 \\
\hline Employees Loyalty & 5 & 5 \\
\hline Work Culture & 5 & 5 \\
\hline $\begin{array}{l}\text { Employee Development and } \\
\text { Training }\end{array}$ & 4 & 5 \\
\hline Competitive Selling Prices & 5 & 4 \\
\hline Research and Product Development & 4 & 5 \\
\hline Sum & 53 & 52 \\
\hline 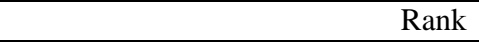 & 1 & 2 \\
\hline
\end{tabular}

\subsection{Input of Decisions "(V)RIO and Business Environment"}

\subsubsection{Internal Environment Analysis}

The resources and capabilities of PT. Velesia which has the greatest strength are employee loyalty and quality control with a score of 0.368 . The resources and capabilities of PT. Velesia, which has the most minor strength is a marketing media network with a score of 0.222 , while the resources and capabilities of PT. Velesia, which has the biggest weakness is information technology with a score of 0.074 as well as research and product development with a score of 0.092

Table 3. IFE Matrix

\begin{tabular}{|c|c|c|c|}
\hline Internal Factor & Weight & Rank & Score \\
\hline \multicolumn{4}{|c|}{ Strengths } \\
\hline Competitive Selling Prices & 0.074 & 4 & 0.296 \\
\hline Brand Awareness & 0.092 & 3 & 0.276 \\
\hline Marketing Media Network & 0.074 & 3 & 0.222 \\
\hline Market Expansion & 0.092 & 3 & 0.276 \\
\hline Key Supplier & 0.074 & 4 & 0.296 \\
\hline Quality Control & 0.092 & 4 & 0.368 \\
\hline Work Culture & 0.074 & 3 & 0.222 \\
\hline Employees Loyalty & 0.092 & 4 & 0.368 \\
\hline
\end{tabular}




\begin{tabular}{|c|c|c|c|}
\hline Information Technology & 0.074 & 1 & 0.074 \\
\hline Procurement Management & 0.092 & 2 & 0.184 \\
\hline $\begin{array}{l}\text { Employee Development and } \\
\text { Training }\end{array}$ & 0.074 & 2 & 0.148 \\
\hline $\begin{array}{l}\text { Research and Product } \\
\text { Development }\end{array}$ & 0.092 & 1 & 0.092 \\
\hline Total & 1 & & 2.988 \\
\hline
\end{tabular}

\subsubsection{External Environment Analysis}

In the EFE Matrix, the biggest opportunity for PT. Velesia is the development of online shopping with a score of 0.552 , while the biggest threats of the external factors for PT. Velesia is the regulations of community activity restrictions (PPKM), as it impacts consumption of shopping products, which are the character/product groups offered by PT. Velesia, with a score of 0.552 .

Table 4. EFE Matrix

\begin{tabular}{|c|c|c|c|}
\hline External Factor & Weight & Rank & Score \\
\hline \multicolumn{4}{|c|}{ Opportunity } \\
\hline $\begin{array}{l}\text { Regional Investment } \\
\text { Promotion Programs }\end{array}$ & 0.111 & 3 & 0.333 \\
\hline $\begin{array}{l}\text { Potential for the Craft and } \\
\text { Fashion Industry }\end{array}$ & 0.111 & 3 & 0.333 \\
\hline Online Shopping Culture & 0.138 & 4 & 0.552 \\
\hline Technological Developments & 0.138 & 3 & 0.414 \\
\hline $\begin{array}{l}\text { Environmentally Friendly } \\
\text { Packaging }\end{array}$ & 0.111 & 4 & 0.444 \\
\hline $\begin{array}{l}\text { PITPT Programs and } \\
\text { Acceleration of Tax Refunds }\end{array}$ & 0.111 & 3 & 0.333 \\
\hline \multicolumn{4}{|c|}{ Threats } \\
\hline $\begin{array}{l}\text { Regulations of Community } \\
\text { Activity Restrictions (PPKM) }\end{array}$ & 0.138 & 4 & 0.552 \\
\hline $\begin{array}{l}\text { Indonesia's Economic } \\
\text { Instability }\end{array}$ & 0.138 & 3 & 0.414 \\
\hline Total & 1 & & 3.375 \\
\hline
\end{tabular}

\subsection{Output Screen "Strategy"}

The results of the grand strategy matrix analysis indicate that PT. Velesia is in quadrant I, and the right choice of competitive strategy for PT. Velesia is market penetration, development, and product development [8].

The penetration strategy that can be done by PT. Velesia is to increase promotions, maintain prices, and increase workforce competence in order to be able to capture and fulfill market desires with the products they produce and cooperate with other companies to strengthen the company's competitive position. The market development strategy that the company can carry out is to expand the market segment targeted by the company by adding product differentiation, and the company can expand the market segments both demographically and geographically - furthermore, PT. Velesia can carry out product development strategy by intensifying market research to more accurately identify consumer wants and needs related to the product and correctly translate them into product strategies. They can figure out the types of bag products that are becoming a trend, create new product lines, improve product quality, strengthen product value, and make an effort to design products that are more in line with the market or consumer needs.

\section{CONTRIBUTION OF THE STUDY}

The results of this study provide an overview related to the fashion industry or another industry with the same character; the results of this study identified opportunities and threats that arise from the environment. By knowing the strengths and weaknesses of a business, as we know that each business has different strengths and weaknesses, this research provides recommendations on what strategies can be considered when these strengths and weaknesses are met with the external environment with existing opportunities and threats. The results of this study also provide recommendations and support that the business can combine several strategies in choosing a business strategy. This combination is used based on environmental changes that are intense according to consumer tastes. The strategy chosen is more oriented to consumer needs. To be more precise with consumer needs, businesses must be able to choose parts of the market that have high potential to absorb products and become more focused

\section{REFERENCES}

[1] Yohana Artha Uly. Nilai Transaksi E-commerce di RI Diprediksi Tembus Rp 330,7 triliun pada 2021, money.kompas.com, 16 August 2021 [Online].

Available: https://money.kompas.com/read/2021/08/16/110 522226/nilai-transaksi-e-commerce-di-ridiprediksi-tembus-rp-3307-triliun-pada-2021 [Accessed 30 August 2021]

[2] Caesar Akbar. Sumbang PDB Rp. 1.100 T Sandiaga Yakin Ekonomi Kreatif Lokal Mampu Mendunia, bisnis.tempo.co, 18 January 2021 [Online]. Available: https://bisnis.tempo.co/read/1424285/sumbangpdb-rp-1-100-t-sandiaga-yakin-ekonomi-kreatif- 
lokal-mampu-mendunia/full\&view=ok

[Accessed: 24 February 2021].

[3] Agarwal, Ravi; Grassl, Wolfgang; Pahl, Joy; Meta-SWOT: Introducing a new strategic planning tool. Journal of Business Strategy vol.33, pp 12-21, 2012

[4] Amin, Pirmohammadzadeh; Saeid, Kamyabi; Mohammad, Reza Zandmoghadam; Strategic Planning and Sociology in Improving the Quality of Life and Sustainable Development of Cities in Arid Regions Climates with Emphasis on MICE Tourism using Meta -SWOT and SOAR Techniques; Iranian journal of educational Sociology (Interdisciplinary Journal of Education) Volume 4, Number 2, June 2021 Vol 4 no 2; June 2021

[5] J. David Hunger; Thomas L. Wheelen, Manajemen Strategis. Yogyakarta: ANDI, 2003.

[6] Nuno Cardeal; Nelson Antonio. Value, rare, inimitable, reources and organization (VRIO) resources or valuable, rare, inimitable resources (VRI) capabilities: What leads to competitive advantage? African Journal of Business Management, 10159-10170, 2012

[7] Claudinia Cantika Ovilia Laongan, Anilisis Pengembangan Strategi Bersaing Menggunakan Pendekatan Meta-SWOT pada PT. Astika Mentari Farma. Malang: Universitas Brawijaya, 2019

[8] Fred R. David; Forest R. David. Manajemen Strategi. Jakarta: Salemba 4, 2016

[9] Habib, Nasirifar, Abbas, Bakhshandeh Nosrat; Strategic model of integrated management of urban boundaries in Bandar-e Emam Khomeyni based on Meta-SWOT technique; International Journal of Development and Sustainability Volume 7 Number 12 (2018): Pages 2909-2926

[10] Ibrahim, Metodologi Penelitian Kualitatif. Bandung: Alfabeta, 2018.

[11] Ida Yulianti, Metode Analisis RBV (Rources Based View) Untuk Merumuskan Keunggulan Bersaing Pada PT Ciesta Mandiri Sejahtera Cabang jember. Jember: Universitas Muhammadiyah Jember, 2019.
[12] John A. Pearce; Richard B. Robinson Jr, Manajemen Strategis: Formulasi, Implementasi, dan Pengandilan. Jakarta: Salemba Empat, 2013.

[13] Ipak Ayu H Nurcahya. Kontribusi Industri Kreatif Rp1.102 Triliun, ekonomi.bisni.com, March. 9, 2020 [Online] Available: https://ekonomi.bisnis.com/read/20200309/257/ 1211032/kontribusi-industri-kreatif-rp1.102triliun [Accessed: 20 January 2021]

[14] Phillip Kotler; Kevin Lane Keller, Marketing Management. 14th Ed. New Jersey: Pearson, 2012.

[15] Mudrajad Kuncoro, Strategi Bagaimana Meraih Keunggulan Kompetitif. Jakarta: Erlangga, 2005 .

[16] Menteri Perdaganan Republik Indonesia. Peraturan Menteri Perdagangan Republik Indonesia Nomor 77 Tahun 2019 Tentang Perubahan Kedua Atas Peraturan Menteri Perdagangan NOMOR 85/MDAG/PER/10/2015 Tentang Ketentuan Impor Tekstil dan Produk Tekstil. Menteri Perdagangan Republik Indonesia, 2019.

[17] Milka Ongkowijaya, Analisis Strategi Bersaing Pada PT. Makmur Bersama Properti. Surabaya: Universitas Kristen Petra, 2019.

[18] Muhammad Danang Syaparruddin, Analisis Pengembangan Strategi Bersaing Pada PT. Putra Seratai Sebagai Distributor Elpiji Bersubsidi 3 kg PT. Pertamina (persero) Di Kota Balikpapan Kalimantan Timur. Malang: Universitas Brawijaya, 2019.

[19] Sugiyono. Metode Penelitian Bisnis (Pendekatan Kuantitatif, Kualitatif, Kombinasi, dan RnD). Bandung: Alfa Beta, 2018.

[20] Robbins, Stephen P.; Coulter, Mary. Management. 11th Ed. New Jersey: Pearson, 2012.

[21] Robbins, Stephen P.; Coulter, Mary. Manajemen Edisi 13. Jakarta: Erlangga, 2016. 